\title{
Greenhouse Gas Emissions from Hydropower Reservoirs
}

Amit Kumar and M. P. Sharma

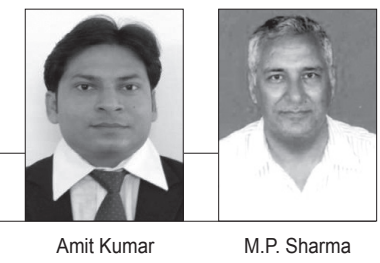

Abstract: Hydropower reservoirs are found to emit about 35-70 times less greenhouse gas (GHG) compared to thermal power plants. The emissions not only depend on the type of eco-region in which the reservoir is located but also on the reservoir characteristics and water quality parameters. This paper reports the results of the impact of reservoir parameters and water quality characteristics on GHG emission from tropical, temperate and boreal reservoirs. For this purpose, linear equations are developed but the regression coefficient is found very poor. The $\mathrm{R}^{2}$ range for $\mathrm{CO}_{2}$ is $5 \times 10^{-5}$ to 0.36 for tropical, temperate and boreal reservoirs and the $\mathrm{R}^{2}$ ranges for $\mathrm{CH}_{4}$ is $0.004-$ 0.244 respectively, which is far lower than 0.90 , and cannot be accurately used for prediction. Thereafter, empirical regression equations are developed to see the combined impact of reservoir parameters and $R^{2}$ is found as 0.48 for $\mathrm{CO}_{2}$ and 0.16 for $\mathrm{CH}_{4}$ for tropical, 0.34 and 0.37 for $\mathrm{CO}_{2}$ and $\mathrm{CH}_{4}$ respectively for temperate and 0.51 and 0.26 for boreal reservoirs. The $\mathrm{R}^{2}<0.90$ indicates that these equations cannot be used to accurately predict the emissions, but can be used to get some idea about emissions from the reservoirs.

Key words: Greenhouse gases, hydropower reservoir, eco-region, emissions

\section{Introduction}

$\mathbf{I}$ n view of global warming, the greenhouse gas (GHG) emission from the earth surface has become a serious environmental issue since the recent past. Artificial reservoirs, particularly in the tropics, are identified as significant $\mathrm{CO}_{2}$ and $\mathrm{CH}_{4}$ emitters. The major GHGs are $\mathrm{CO}_{2}, \mathrm{CH}_{4}$ and $\mathrm{N}_{2} \mathrm{O}$ emitted from both natural aquatic (lakes, rivers, estuaries, and wetlands) and terrestrial ecosystems (forest, soils) as well as from the anthropogenic sources contributing to the global warming. The global warming potential (GWP) of $\mathrm{CH}_{4}$ is 21 times higher than $\mathrm{CO}_{2}$ over a period of 100 years showing that $\mathrm{CH}_{4}$ is more harmful than $\mathrm{CO}_{2}$ (IPCC 2007). St. Louis et al (2000) have studied the current area covered by hydropower reservoirs worldwide representing about $25 \%$ of the total area used for humanmade freshwater systems such as irrigation, water supply, energy generation etc. Hydropower reservoirs are reported to emit about 35-70 times less GHG than thermal power plants, even though all human-made hydropower reservoirs emit $<16 \%$ of the $\mathrm{CO}_{2}$ and $\mathrm{CH}_{4}$ emission. Escrito Por. E (2011) have found that only $17 \%$ of the potential of hydropower reservoirs has yet been exploited, but the magnitude of GHG emissions varies with reservoir age, size and location as well as water quality. St. Louis et al (2000) reported that $\mathrm{CH}_{4}$ from reservoirs represent $12 \%$ of global $\mathrm{CH}_{4}$ emission and $90 \%$ of it is contributed by reservoirs located in the tropics. Guérin et al (2007) found that higher temperature in the tropics with large amount of organic matter accumulated in reservoirs leads to high $\mathrm{CO}_{2}$ and $\mathrm{CH}_{4}$ emissions. Besides, there are significant differences in emissions from reservoirs located in different climatic zones. Huttunen et al (2002) observed that the reservoirs located in the same climatic zones have significant differences in GHG emissions. Abril et al (2005) and Teodoru et al (2010) found that, as the flooded vegetation and soil organic matter are potential sources of GHG in hydropower reservoirs, the initial flooding phase is associated with higher rates of both bacterial activity and GHG production. The organic matter enters the reservoir from the flooded area, primary production in the reservoir and from the river upstream. Pathways of GHG emissions include diffusing and bubbling in the reservoir itself and in the river downstream. Significant amounts of gases are released when the water passes through the turbine and the spillway. $\mathrm{CO}_{2}$ emissions also result from $\mathrm{CH}_{4}$ oxidation by anaerobic bacteria that thrive in poorly oxygenated aquatic environments such as sedimentwater interface and thermocline zones. The amount of GHG emitted depends not only on the type of eco-region where the reservoir is located, but also on the reservoir parameters like age, depth, temperature, volume, input of organic matter. Since very little emission data is available only from hydropower reservoirs in Canada, France and Brazil; and so it is difficult to establish any relationship between GHG emissions and water quality and reservoir parameters. Significant uncertainties are found in the emission data with respect to water quality and reservoir characteristics. An attempt has been made in this paper to gather the water quality, reservoir characteristics and GHG emission data from literature and to establish equations with respect to individual parameters to study the effectiveness of parameters and to develop empirical equations based on all the data. These empirical equations can be used to predict the GHG emissions provided the data for any reservoir in a given eco-region is available.

\section{Mechanisms of GHG Emissions}

The type of gas and its magnitude of emission from a multi-component aquatic environment are governed by the complex phenomena occurring within the water body. As shown in Figure 1 (IPCC 2007), the Pathways for $\mathrm{GHG}$ emissions $\left(\mathrm{CO}_{2}\right.$ and $\left.\mathrm{CH}_{4}\right)$ to the atmosphere from reservoirs include: (i) molecular diffusion at the water-air interface, studied by Roland et al (2010) and Teodoru et al (2010), (ii) bubbling from the sediment, 
studied by Abe et al (2005) and Lime (2005), (iii) degassing from water passing through the turbines, studied by Kemenes et al (2007, 2011), (iv) turbulent degassing in downstream rivers, studied by Guerin et al (2006) and diffusive fluxes of $\mathrm{CO}_{2}$ and $\mathrm{CH}_{4}$ at the water-atmosphere interface which are dependent on the existence of a concentration gradient between these two compartments. If the water at the surface of a reservoir is supersaturated with $\mathrm{CO}_{2}$ or $\mathrm{CH}_{4}$ in relation to the atmosphere, gas fluxes occur towards the atmosphere. If, on the other hand, the surface water is under-saturated in relation to the atmosphere, gas fluxes are from the atmosphere to the water. In the latter case, the reservoir surface represents a sink of atmospheric carbon. The amount of GHG flowing through the water-atmosphere interface depends on gas solubility in water. Thus, GHG emissions through diffusion tend to be higher in reservoirs located in warmer regions and at lower altitudes. The surface of reservoirs are usually dominated by diffusive fluxes of $\mathrm{CO}_{2}$, even in cases, where bottom anoxia leads to high $\mathrm{CH}_{4}$ production due to the intense oxidation of diffusive $\mathrm{CH}_{4}$ by anaerobic bacteria above the interface between anoxic and oxygenated water layers was studied by Barros et al (2011). On the other hand, Delsontro et al (2010) observed that the GHG emissions through bubbling are dominated by $\mathrm{CH}_{4}$, perhaps, due to the very low $\mathrm{CH}_{4}$ solubility in water, which permits the formation of bubbles of varying sizes from 2 to $8 \mathrm{~mm}$. The bubbles are usually formed in the sediment of reservoirs under anoxic conditions. Most of the $\mathrm{CH}_{4}$ emissions in shallow reservoirs occur through bubbling, whereas $\mathrm{CH}_{4}$ bubbles are usually dissolved in the water before reaching the surface in deep reservoirs. The process of energy generation from hydroelectric reservoirs leads to two pathways of GHG emission that do not occur in artificial reservoirs built for other purposes (e.g. irrigation, water supply, flood control, and aquaculture): turbulent degassing of water passing through turbines (energy generation utilities) and degassing downstream of dams.

The water inlet to generate energy is frequently located in medium or lower parts of the dam which means that water from deep layers of the reservoirs passes through the turbines. These deep water layers are usually $\mathrm{CO}_{2}$ and $\mathrm{CH}_{4}$ - rich due to both high mineralization rates and high water pressure (i.e. high gas solubility). Kemenes et al (2007) found that by passing water through the turbines, the gases are exposed to low pressure and high temperature conditions favoring rapid emissions to the atmosphere. Despite higher GHG emissions at the turbines, high amounts of both $\mathrm{CO}_{2}$ and $\mathrm{CH}_{4}$ remain dissolved in the water downstream of the dams. Guerin et al (2006) observed that the GHG produced in reservoirs may be encountered at sites as far as $40 \mathrm{~km}$ downstream of the dam. $\mathrm{CH}_{4}$ produced by anaerobic processes is transported either by diffusion or ebullition to the atmosphere and is oxidized in the water column and emitted as $\mathrm{CO}_{2}$, as studied by Delsontro et al (2010) and Tremblay et al (2004).

\section{Data Collection}

As stated above, the data available on GHG emissions is very much scarce and so the data on $\mathrm{CO}_{2}$ and $\mathrm{CH}_{4}$ emissions have been generated based on studies reported in the literature (Barros et al 2011). For this purpose, the reservoirs are categorized into three eco-regions based on latitudinal boundary ranges: tropical $\left(0-25^{\circ}\right)$, temperate $\left(25-50^{\circ}\right)$ and boreal $\left(50-70^{\circ}\right)$. The data from these reservoirs was extracted with respect to age, mean depth, area, volume, residence time, input of Dissolved Organic Carbon (DOC) and Total Phosphate (TP) including GHG emission. In all, emissions data from 154 hydropower reservoirs was collected and analyzed for individual parameters to develop linear relationships using Mini Tab software. The relationship between $\mathrm{CO}_{2}$ emissions and parameters for reservoirs located in the three eco-regions is given in Table 1 and that between $\mathrm{CH}_{4}$ emissions vs reservoir parameters is given in Table 2. Therefore, the empirical regression equations using all the parameters for $\mathrm{CO}_{2}$ and $\mathrm{CH}_{4}$ are given in Table 3 . The coefficient of $\mathrm{R}^{2}$ given in Table 1 shows that there is some relation between $\mathrm{CO}_{2}$ vs reservoir volume $\left(\mathrm{R}^{2}=0.32\right)$, $\mathrm{CO}_{2}$ vs age $(0.36)$ and $\mathrm{CO}_{2}$ vs DOC $\left(\mathrm{R}^{2}=0.26\right)$ while Table 2 shows that there is relatively better relation between $\mathrm{CH}_{4}$ and reservoir volume $\left(\mathrm{R}^{2}=0.22\right)$ and $\mathrm{CH}_{4}$ vs mean depth (0.24).

The validation/verification has yielded huge differences between the observed and predicted values indicating that these correlations do not hold good for the prediction of GHG emissions due to considerable uncertainties owing to the complex environmental conditions prevailing in the water bodies. At the same time, the productions of GHG gases become difficult due to interferences by large number of organic and inorganic (metallic) pollutants present in the water. Therefore, these empirical equations can be tentatively used only to have a rough idea of GHG gases but no significant relation is found that can be used for GHG prediction accurately. Table 3 gives the empirical equations developed for $\mathrm{CO}_{2}$ and $\mathrm{CH}_{4}$ using all the parameters of reservoirs located in the different eco-regions.

\section{Results and Discussions}

Table 1 show that when the $\mathrm{CO}_{2}$ emission from reservoirs located in the three eco regions were analyzed with respect to an individual parameter of the reservoir, the $\mathrm{R}^{2}$ ranges from $5 \times 10^{-5}$ to 0.09 for tropical, 0.002 to 0.16 for temperate, and 0.001 to 0.36 for boreal reservoirs. The Table 2 shows that when the $\mathrm{CH}_{4}$ emission were analyzed for the individual parameter, the $\mathrm{R}^{2}$ range from 0.004 to 0.217 for tropical, 0.012 to 0.244 for temperate and 0.024 to 0.121 for boreal reservoirs. The empirical regression equation developed using all the parameters are given in Table 3, which shows that the coefficient of $\mathrm{R}^{2}$ as 0.48 for tropical for $\mathrm{CO}_{2}$ and 0.16 for $\mathrm{CH}_{4}, 0.51$ for boreal for $\mathrm{CO}_{2}$ and 0.26 for $\mathrm{CH}_{4}$ and very poor for temperate 0.31 for $\mathrm{CO}_{2}$ and 0.37 for $\mathrm{CH}_{4}$. The significant difference in observed and predicted 
emissions can be explained by the fact that the water quality as well as reservoir characteristics of one area cannot be related to another reservoir due to the complex aquatic environment and associated variability.

Coefficients of $\mathrm{R}^{2}$ have been calculated for all the parameters as well as with respect to less number of parameters and the results are given in Table 4. The table shows that when the numbers of reservoir parameters are reduced, $\mathrm{R} 2$ value also decreases. $\mathrm{R}^{2}$ for $\mathrm{CO}_{2}$ fluxes for all the parameters in tropical reservoir are 0.48 which decreases as the number of parameters is reduced sequentially. Similarly, $\mathrm{R}^{2}$ for $\mathrm{CH}_{4}$ fluxes is very less i.e. 0.16 for all and 0.004 for only one parameter. In temperate reservoirs, $\mathrm{R}^{2}$ for $\mathrm{CO}_{2}$ is 0.27 while it is 0.37 for $\mathrm{CH}_{4}$ fluxes for all parameters (0.199) and 0.225 only for 2 parameters for $\mathrm{CO}_{2}$ and $\mathrm{CH}_{4}$ respectively. Further, $\mathrm{R}^{2}$ for $\mathrm{CO}_{2}$ flux is 0.51 while it is 0.26 for $\mathrm{CH}_{4}$ for all the parameters in a boreal reservoir. Similarly, it is 0.197 for $\mathrm{CO}_{2}$ and 0.224 for $\mathrm{CH}_{4}$ for single parameter only. The above results indicate that $\mathrm{R}^{2}$ for $\mathrm{CO}_{2}$ is more than $\mathrm{R}^{2}$ for $\mathrm{CH}_{4}$ in a temperate reservoir. It is 0.27 for $\mathrm{CO}_{2}$ and 0.37 for $\mathrm{CH}_{4}$, while it is 0.51 for $\mathrm{CO}_{2}$ and 0.26 for $\mathrm{CH}_{4}$ for a boreal reservoir for all the parameters. Since $\mathrm{R}^{2}$ in all the cases is $<0.90$; therefore, these values cannot be used to predict GHG emissions but can be helpful in giving an idea about the extent of emissions in reservoirs located in a particular eco-region when all the parameters are used.

Figures 2, 3 and 4 compare the predicted and observed $\mathrm{CO}_{2}$ fluxes for 32 reservoirs in the tropical region, 16 reservoirs for $\mathrm{CH}_{4}$ fluxes in temperate region and 17 reservoirs for $\mathrm{CO}_{2}$ fluxes in the boreal eco-region. It can be seen that in some reservoirs, there is a large difference between the predicted and observed emissions compared to very small difference for other reservoirs. These results indicate high uncertainty in the water bodies due to the interferences of different pollutants and as such, these relationships cannot be accurately used for prediction. Dones et al (2007) found that the uncertainty in measuring emissions from hydropower reservoirs is attributed to the rate of decomposition, which in turn, is affected by temperature, geographical location, reservoir age, the amount and type of vegetation, water residence time, reservoir shape and volume. Teodoru et al (2010), Tremblay et al (2010) and Siyue Li. X.X. Lu (2012) also found that the reservoir surface area and paucity of carbon emission are related to the ecological zone and GHG emission from hydroelectric reservoirs are globally under-estimated .

In view of the above, it is concluded that $\mathrm{R}^{2}$ for both $\mathrm{CO}_{2}$ and $\mathrm{CH}_{4}$ is observed to be 0.50 when the combined impact of all the parameters are studied and can be

\begin{tabular}{|c|c|c|c|c|c|c|c|}
\hline \multirow{2}{*}{ S.No. } & \multirow{2}{*}{ Parameters } & \multicolumn{2}{|l|}{ Tropical Zone } & \multicolumn{2}{|c|}{ Temperate Zone } & \multicolumn{2}{|l|}{ Boreal Zone } \\
\hline & & Equation & $\mathbf{R}^{2}$ & Equation & $\mathbf{R}^{2}$ & Equation & $\mathbf{R}^{2}$ \\
\hline 1. & $\mathrm{CO}_{2}$ flux v/s Age & $y=-37.037 x+3588.5$ & 0.084 & $y=2.5355 x+562.6$ & 0.002 & $y=-35.395 x+2264.8$ & 0.361 \\
\hline 2. & $\mathrm{CO}_{2}$ flux v/s DOC & $y=0.2217 x+2396$ & 0.065 & $y=0.0146 x+124.65$ & 0.039 & $y=1.8946 x+1434.9$ & 0.265 \\
\hline 3. & $\mathrm{CO}_{2}$ flux v/s TP & $y=-19.058 x+2850.2$ & 0.016 & $y=3.7146 x+1057.8$ & 0.005 & $y=849.94 x+1597.1$ & 0.045 \\
\hline 4. & $\mathrm{CO}_{2}$ flux v/s Residence Time & $y=-2.4711 x+3288.8$ & 0.046 & $y=0.072 x+595.53$ & 0.057 & $y=-0.0072 x+1650.5$ & 0.001 \\
\hline 5. & $\mathrm{CO}_{2}$ flux v/s Volume & $y=-37.048 x+3995$ & 0.047 & $y=8.9425 x+903.1$ & 0.027 & $y=-87.967 x+2797.1$ & 0.316 \\
\hline 6 & $\mathrm{CO}_{2}$ flux v/s Area & $y=-37.048 x+3995$ & 0.047 & $y=2.8627 x+1158.7$ & 0.001 & $y=0.0588 x+1154.4$ & 0.002 \\
\hline 7 & $\mathrm{CO}_{2}$ flux v/s Mean Depth & $y=-0.6123 x+3026$ & 5E-05 & $y=10.734 x+1076$ & 0.160 & $y=-14.709 x+1965.2$ & 0.052 \\
\hline
\end{tabular}

Table 1. Linear Correlation of Tropical, Temperate and Boreal Zones for $\mathrm{CO}_{2}$ Emissions.

\begin{tabular}{|r|l|l|l|l|l|l|c|}
\hline \multirow{2}{*}{ S.No. } & \multirow{2}{*}{ Parameters } & \multicolumn{2}{|c|}{ Tropical Zone } & \multicolumn{2}{c|}{ Temperate Zone } & \multicolumn{2}{c|}{ Boreal Zone } \\
\cline { 3 - 8 } & & \multicolumn{1}{|c|}{ Equation } & $\mathbf{R}^{\mathbf{2}}$ & Equation & $\mathbf{R}^{\mathbf{2}}$ & Equation & $\mathbf{R}^{\mathbf{2}}$ \\
\hline 1. & $\mathrm{CH}_{4}$ flux v/s Age & $\mathrm{y}=-6.3165 \mathrm{x}+365.95$ & 0.073 & $\mathrm{y}=0.4137 \mathrm{x}+32.961$ & 0.066 & $\mathrm{y}=0.4242 \mathrm{x}+12.499$ & 0.024 \\
\hline 2. & $\mathrm{CH}_{4}$ flux v/s DOC & $\mathrm{y}=-0.0107 \mathrm{x}+210.68$ & 0.014 & $\mathrm{y}=0.0022 \mathrm{x}+26.455$ & 0.050 & $\mathrm{y}=-0.0502 \mathrm{x}+35.229$ & 0.050 \\
\hline 3. & $\mathrm{CH}_{4}$ flux v/s TP & $\mathrm{y}=-5.1535 \mathrm{x}+256.43$ & 0.071 & $\mathrm{y}=8.092 \mathrm{x}+1283$ & 0.012 & $\mathrm{y}=9.6659 \mathrm{x}+15.644$ & 0.009 \\
\hline 4. & $\mathrm{CH}_{4}$ flux v/s Residence Time & $\mathrm{y}=0.1077 \mathrm{x}+177$ & 0.004 & $\mathrm{y}=-0.002 \mathrm{x}+29.09$ & 0.039 & $\mathrm{y}=-0.003 \mathrm{x}+23.337$ & 0.032 \\
\hline 5. & $\mathrm{CH}_{4}$ flux v/s Volume & $\mathrm{y}=-16.916 \mathrm{x}+537.87$ & 0.217 & $\mathrm{y}=9.3036 \mathrm{x}+919.17$ & 0.028 & $\mathrm{y}=-0.1946 \mathrm{x}+24.05$ & 0.076 \\
\hline 6. & $\mathrm{CH}_{4}$ flux v/s Area & $\mathrm{y}=-0.0289 \mathrm{x}+186.76$ & 0.006 & $\mathrm{y}=11.972 \mathrm{x}+1867.1$ & 0.039 & $\mathrm{y}=-0.0069 \mathrm{x}+31.759$ & 0.058 \\
\hline 7. & $\mathrm{CH}_{4}$ flux v/s Mean Depth & $\mathrm{y}=0.6444 \mathrm{x}+152.28$ & 0.006 & $\mathrm{y}=0.434 \mathrm{x}+4.8494$ & 0.244 & $\mathrm{y}=-0.4016 \mathrm{x}+27.703$ & 0.121 \\
\hline
\end{tabular}

Table 2. Linear Correlations of Tropical, Temperate and Boreal Zones for $\mathrm{CH}_{4}$

\begin{tabular}{|l|l|l|l|l|l|}
\hline S.no. & Eco-region & GHG & \multicolumn{1}{|c}{ Empirical equations } & $\mathbf{R}^{2}$ value \\
\hline \multirow{2}{*}{1.} & \multirow{2}{*}{ Tropical } & $\mathrm{CO}_{2}$ & $\mathrm{~A}_{1}=3343-20.2 \mathrm{~B}+35.6 \mathrm{C}+6.29 \mathrm{D}-113 \mathrm{E}-7.20 \mathrm{~F}-25.3 \mathrm{G}-0.288 \mathrm{H}$ & 0.48 \\
\cline { 3 - 6 } & & $\mathrm{CH}_{4}$ & $\mathrm{~A}_{2}=274+0.31 \mathrm{~B}+2.44 \mathrm{C}+0.50 \mathrm{D}-15.4 \mathrm{E}-0.39 \mathrm{~F}-3.62 \mathrm{G}-0.064 \mathrm{H}$ & 0.16 \\
\hline \multirow{2}{*}{2.} & \multirow{2}{*}{ Temperate } & $\mathrm{CO}_{2}$ & $\mathrm{~A}_{1}=-203+21.8 \mathrm{~B}-0.6 \mathrm{C}-0.73 \mathrm{D}-112 \mathrm{E}+0.033 \mathrm{~F}-0.249 \mathrm{H}$ & 0.34 \\
\cline { 3 - 6 } & $\mathrm{CH}_{4}$ & $\mathrm{~A}_{2}=34.6-0.886 \mathrm{~B}+0.459 \mathrm{C}+0.145 \mathrm{D}-2.33 \mathrm{E}-0.00169 \mathrm{~F}+0.0112 \mathrm{H}$ & 0.37 \\
\hline \multirow{2}{*}{3.} & \multirow{2}{*}{ Boreal } & $\mathrm{CO}_{2}$ & $\mathrm{~A}_{1}=3294-40.7 \mathrm{~B}-38.3 \mathrm{C}-0.620 \mathrm{D}+27.6 \mathrm{E}+0.017 \mathrm{~F}$ & 0.51 \\
\cline { 3 - 6 } & $\mathrm{CH}_{4}$ & $\mathrm{~A}_{2}=24.9+1.06 \mathrm{~B}-1.65 \mathrm{C}-0.0072 \mathrm{D}+0.428 \mathrm{E}+0.00072 \mathrm{~F}$ & 0.26 \\
\hline
\end{tabular}

Table 3. Empirical Equations for Predicting $\mathrm{CO}_{2}$ and $\mathrm{CH}_{4}$ Flux using all the Parameters in Different Eco-Regions.

Where: $\mathrm{A}_{1}=\mathrm{CO}_{2}$ flux, $\mathrm{A}_{2}=\mathrm{CH}_{4}$ flux, $\mathrm{B}=$ Age, $\mathrm{C}=$ Mean depth, $\mathrm{D}=$ Area, $\mathrm{E}=$ Volume, $\mathrm{F}=$ Residential time, $\mathrm{G}=\mathrm{Input}$ of $\mathrm{TP}, \mathrm{H}=$ input of DOC. 


\begin{tabular}{|c|c|c|c|}
\hline \multicolumn{4}{|c|}{ Tropical Reservoir $\left(\mathbf{n = 4 8}\right.$ for $\mathbf{C O}_{\mathbf{2}}, \mathbf{n = 3 2}$ for $\left.\mathbf{C H}_{\mathbf{4}}\right)$} \\
\hline No. of parameters & Parameters & $\left.\mathbf{R}^{\mathbf{2}} \mathbf{( C O}_{\mathbf{2}} \mathbf{F l u x}\right)$ & $\left.\mathbf{R}^{\mathbf{2}} \mathbf{C H}_{\mathbf{4}} \mathbf{F l u x}\right)$ \\
\hline 7 & $\mathrm{~B}, \mathrm{C}, \mathrm{D}, \mathrm{E}, \mathrm{F}, \mathrm{G}, \mathrm{H}$ & 0.480 & 0.160 \\
\hline 6 & $\mathrm{~B}, \mathrm{C}, \mathrm{D}, \mathrm{E}, \mathrm{F}, \mathrm{G}$ & 0.434 & 0.145 \\
\hline 5 & $\mathrm{~B}, \mathrm{C}, \mathrm{D}, \mathrm{E}, \mathrm{F}$ & 0.355 & 0.133 \\
\hline 4 & $\mathrm{~B}, \mathrm{C}, \mathrm{D}, \mathrm{E}$ & 0.176 & 0.132 \\
\hline 3 & $\mathrm{~B}, \mathrm{C}, \mathrm{D}$ & 0.128 & 0.007 \\
\hline 2 & $\mathrm{~B}, \mathrm{C}$ & 0.126 & 0.004 \\
\hline 1 & $\mathrm{~B}$ & 0.102 & 0.004 \\
\hline
\end{tabular}

5 to 0.09 for tropical reservoir, 0.002-0.16 for temperate reservoir and 0.001-0.36 for boreal reservoir, and the $\mathrm{R}^{2}$ range for $\mathrm{CH}_{4}$ is from 0.004 to 0.217 for tropical reservoir, 0.012 to 0.244 for temperate reservoir and 0.024 to 0.121 for boreal reservoir, which, being far lower than 0.90, cannot be used for the prediction of GHG from the reservoirs. Therefore, the empirical regression equations are developed to see the combined impact of all the parameters on GHG emissions.

Temperate Reservoir $\left(\mathrm{n}=14\right.$ for $\mathrm{CO}_{2}, \mathrm{n=16}$ for $\left.\mathrm{CH}_{4}\right)$

\begin{tabular}{|c|c|c|c|}
\hline No. of parameters & Parameters & $\mathbf{R}^{\mathbf{2}}\left(\mathbf{C O}_{\mathbf{2}}\right.$ Flux $)$ & $\mathbf{R}^{\mathbf{2}} \mathbf{C H}_{\mathbf{4}}$ Flux $)$ \\
\hline 6 & $\mathrm{~B}, \mathrm{C}, \mathrm{D}, \mathrm{E}, \mathrm{F}, \mathrm{H}$ & 0.266 & 0.369 \\
\hline 5 & $\mathrm{~B}, \mathrm{C}, \mathrm{D}, \mathrm{E}, \mathrm{F}$ & 0.228 & 0.335 \\
\hline 4 & $\mathrm{~B}, \mathrm{C}, \mathrm{D}, \mathrm{E}$ & 0.212 & 0.309 \\
\hline 3 & $\mathrm{~B}, \mathrm{C}, \mathrm{D}$ & 0.209 & 0.237 \\
\hline 2 & $\mathrm{~B}, \mathrm{C}$ & 0.199 & 0.225 \\
\hline 1 & $\mathrm{~B}$ & 0.197 & 0.224 \\
\hline
\end{tabular}

\begin{tabular}{|c|c|c|c|}
\hline \multicolumn{4}{|c|}{ Boreal Reservoir $\left(\mathbf{n = 1 6}\right.$ for $\mathbf{C O}_{\mathbf{2}}, \mathbf{n = 1 4}$ for $\left.\mathbf{C H}_{\mathbf{4}}\right)$} \\
\hline No. of parameters & Parameters & $\mathbf{R}^{\mathbf{2}}\left(\mathbf{C O}_{\mathbf{2}}\right.$ Flux $)$ & $\mathbf{R}^{\mathbf{2}}\left(\mathbf{C H}_{\mathbf{4}}\right.$ Flux $)$ \\
\hline 5 & $\mathrm{~B}, \mathrm{C}, \mathrm{D}, \mathrm{E}, \mathrm{F}$ & 0.507 & 0.261 \\
\hline 4 & $\mathrm{~B}, \mathrm{C}, \mathrm{D}, \mathrm{E}$ & 0.506 & 0.260 \\
\hline 3 & $\mathrm{~B}, \mathrm{C}, \mathrm{D}$ & 0.390 & 0.243 \\
\hline 2 & $\mathrm{~B}, \mathrm{C}$ & 0.134 & 0.232 \\
\hline 1 & $\mathrm{~B}$ & 0.112 & 0.016 \\
\hline
\end{tabular}

Table 4. Coefficients of $R^{2}$ of Tropical, Temperate and Boreal Zones with Individual and Combined Parameters.

Where: $\mathrm{n}=$ Number of reservoirs, $\mathrm{A}_{1}=\mathrm{CO}_{2}$ flux, $\mathrm{A}_{2}=\mathrm{CH}_{4}$ flux, $\mathrm{B}=$ Age,

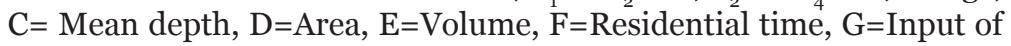
$\mathrm{TP}, \mathrm{H}=$ input of DOC.

used for prediction. Further, the GHG emissions are significantly influenced by reservoir characteristics and water quality parameters in boreal reservoirs for $\mathrm{CO}_{2}$ (o.51) and $\mathrm{CH}_{4}$ (o.37) in temperate zone as compared to reservoirs located in other eco-regions. The study also found that very limited experimentally measured emission data are available but more efforts are required to measure more and more GHG emissions in different reservoirs located in different climatic conditions. Since GHG emissions are highly related to water quality, developing models for predicting water quality can be used to predict anoxic waters with good confidence.

\section{Conclusions}

The data on the effect of water quality parameters and hydropower reservoir characteristics on GHG emissions is very much scarce. Accordingly, water quality and reservoir characteristics and GHG emission data were extracted from 154 reservoirs located in tropical, boreal and temperate eco-regions. To study the impact of reservoir parameters on the GHG emissions, linear equations are developed but the regression coefficient is found to be very poor; the $\mathrm{R}^{2}$ ranges for $\mathrm{CO}_{2}$ from $5 \times 10-$

These correlations are found to have regression coefficient of $\mathrm{R}^{2}>0.40$ for $\mathrm{CO}_{2}$ for tropical and boreal reservoirs, very poor $\mathrm{R}^{2}<0.40$ for temperate reservoirs while for $\mathrm{CH}_{4}$, it is $\mathrm{R}^{2}<0.40$ for all tropical, temperate and boreal reservoirs. These correlations could be tentatively used to get an idea about the level of emissions, as the GHG measurement at site is difficult and no perfect measurement techniques are available. The data analyses have indicated high uncertainty in water bodies due to the interferences of different pollutants and as such, these relationships cannot be usefully used for the prediction. Results also show that when the number of reservoir parameters is reduced, the $\mathrm{R}^{2}$ also decreases. The $\mathrm{CO}_{2}$ emissions are found to be affected significantly by the reservoir age, input of DOC, reservoir volume as evidenced by the relatively higher $\mathrm{R}^{2}$ range from $0.26-0.36$ for boreal reservoirs. However, there is huge scope of R \& D in the area of GHG emissions from water bodies for an understanding of the actual phenomenon occurring in the natural aquatic environment.

Amit Kumar is pursuing his Masters of Technology degree in "Environmental Management of Rivers and Lakes" in the area of greenhouse gas emissions from hydropower reservoirs.

Corresponding address: amit.aglog@gmail.com

M.P. Sharma, Ph.D., has been working as Associate Professor at Alternate Hydro Energy Center, Indian Institute of Technology, Roorkee (India), since the last 25 years. His area of research are renewable energy with special reference to bio-diesel production and utilization, Modeling of IRES, Hybrid Energy Systems, induction generators, EIA of renewable energy projects, Energy and Environment conservation, conservation of water bodies, water quality assessment and GHG emissions from reservoirs and lakes.

Corresponding address: mpshafah@iitr.ernet.in 


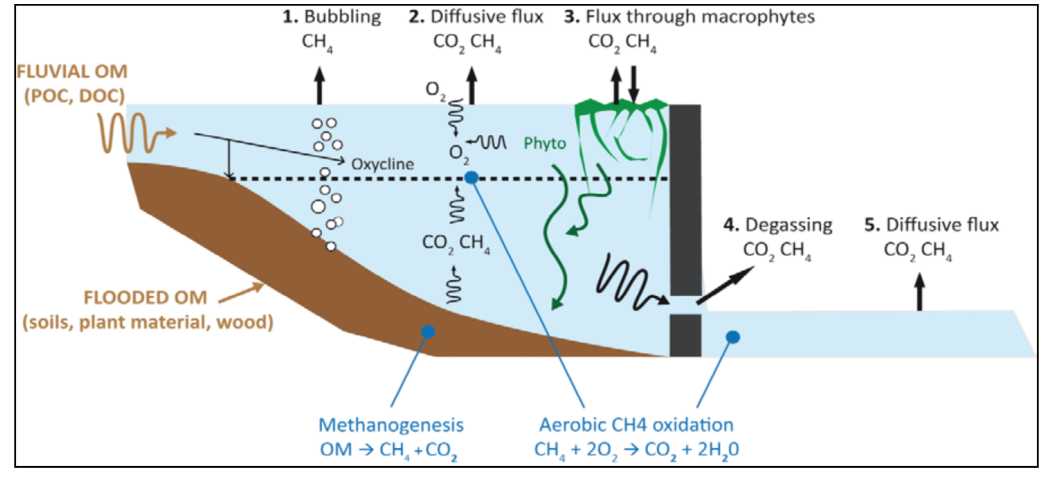

Figure 1. Pathways of GHG Emissions from a Reservoir (IPCC 2007).

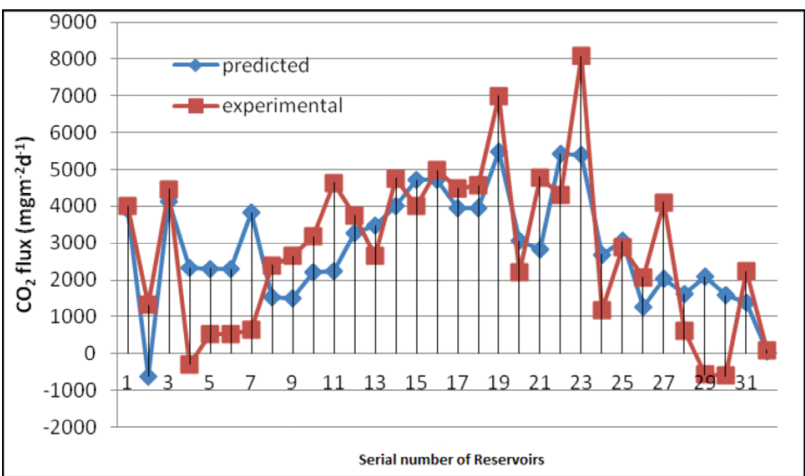

Figure 2. Comparison between Predicted/Observed $\mathrm{CO}_{2}$ Fluxes for Tropical Reservoir.

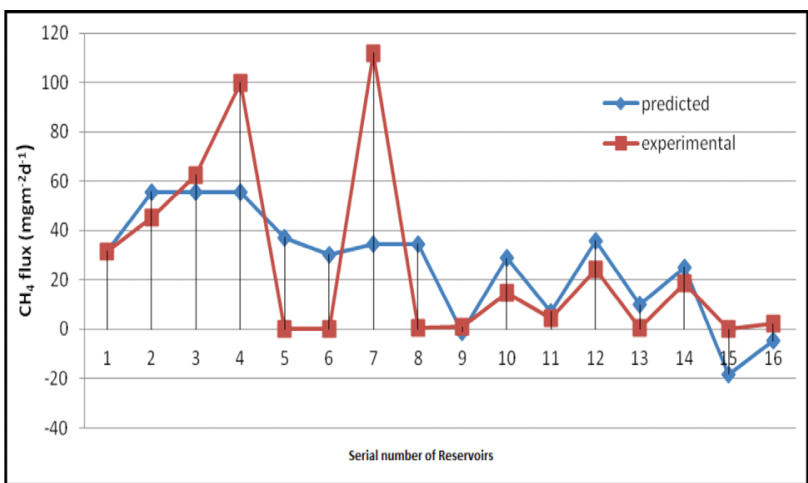

Figure 3. Comparison of Predicted/Observed $\mathrm{CH}_{4}$ Fluxes for Temperate Reservoir.

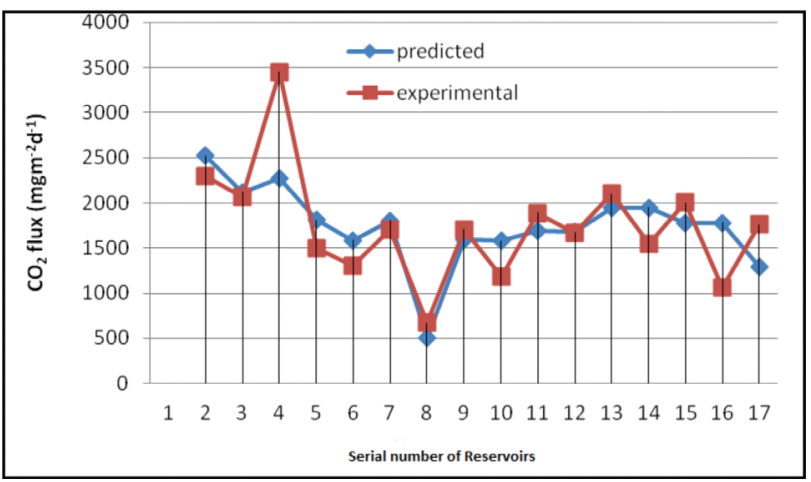

Figure 4. Comparison of Predicted/Observed $\mathrm{CO}_{2}$ Fluxes for Boreal Reservoir.

\section{References}

Abe, D.S., D. A. Donald, C.V.S. Galli, E. Sikar and J.G.

Tundisi, 2005, Sediment greenhouse gases (methane and carbon dioxide) in the Lobo-Broa Reservoir, São
Paulo State, Brazil: Concentrations and diffuse emission fluxes for carbon budget considerations, Lakes \& Reservoirs: Research and Management, Vol.10. No.4, pp. 201209, 1440-1770.

Abril, G., F. Guerin, S. Richard, R. Delmas, C. Galy-Lacaux, P. Gosse, A. Tremblay, L. Varfalvy, M.A. Dos Santos and B. Matvienko, 2005, Carbon dioxide and methane emissions and the carbon budget of a 10-year old tropical reservoir (Petit Saut, French Guiana), Global Biogeochemical Cycles, Vol.19, No.4, Oct, PP. o886-6236.

Barros, N., J.C. Jonathan, J.T. Lars, T.P. Yves, B. David, L.M.H. Vera, D.G. Paul and R. Fabio, 2011, Carbon emission from hydroelectric reservoirs linked to reservoir age and latitude, Nature Geosciences, Vol.4, No.9, Sep, pp, 593-596, 17520894.

Delsontro, T., D.F. McGinnis, S. Sobek, I. Ostrovsky and B. Wehrli, 2010, Extreme Methane Emissions from a Swiss Hydropower Reservoir: Contribution from Bubbling Sediments, Environmental Science \& Technology, vol. 44, No.7, Apr 1, pp. 2419-2425, o013-936X.

Dones, R., C. Bauer, R. Bolliger, B. Burger, T. Heck, A. Roder, P.S. Institut and Villigen, 2007, Life Cycle Inventories of Energy Systems, Results for Current Systems in Switz. and other UCTE Countries, Ecoinvent Report No. 5, Data V2.0.

Escrito Por. E., 2011, Greenhouse gas impact of hydroelectric reservoirs downgraded, <www. hidroenergia.nd $>>$.

Greenhouse gas emissions related to freshwater reservoirs, 2010, World Bank Contract 7150219, Supported by Norwegian NTF-PSI, pp 20.

Guerin, F., G. Abril, S. Richard, B. Burban, C. Reynouard, P. Seyler, and R. Delmas, 2006, Methane and carbon dioxide emissions from tropical reservoirs: Significance of downstream rivers. Geophysical Research Letters, Vol.33. No.21, Nov, pp. 0094-8276. Guérin, F., G. Abril, D. Serça, C. Delon, S. Richard, R. Delmas, A. Tremblay and L. Varfalvy, 2007, Gas transfer velocities of $\mathrm{CO}_{2}$ and $\mathrm{CH}_{4}$ in a tropical reservoir and its river downstream. Journal of Marine Systems, 66: 161-172.

Huttunen, J.T., T.S. Väisänen, S.K. Hellsten, M. Heikkinen, H. Nykänen, H. Jungner, A. Niskanen, M.O. Virtanen, O.V. Lindqvist, O. Nenonen, and P.J. Martikainen, 2002, Fluxes of $\mathrm{CH}_{4}, \mathrm{CO}_{2}$, and $\mathrm{N}_{2} \mathrm{O}$ in hydroelectric reservoirs Lokka and Porttipahta in the northern boreal zone in Finland. Global Biogeochemical Cycles, 16, 1003, DOI: 10, 1029/200oGBoo1316.

IPCC, 2006, Climate change: the scientific basis, Contribution of Working Group I to the Third Assessment Report of the IPCC, New York: Cambridge 
University Press.

IPCC, 2007, Climate Change, Working Group I: The physical science basis, Chapter 2 changes in atmospheric constituents and in radioactive forcing.

Kemenes, A., B.R. Forsberg and J.M. Melack, 2007, Methane release below a tropical hydroelectric dam, Geophysical Research Letters, Vol.34: L1 2809, Jun 23, pp. 0094- 8276.

Kemenes, A., B.R. Forsberg and J.M. Melack, 2011, $\mathrm{CO} 2$ emissions from a tropical hydroelectric reservoir (Balbina, Brazil), Journal of Geophysical ResearchBiogeosciences,Vol.116, Jul, pp. 0148-0227.

Lima, I.B.T., 2005, Bio geochemical distinction of methane releases from two Amazon hydro reservoirs, Chemosphere, Vol.59, No.11, pp. 1697-1702, 00456535 .

Roland, F., L.O. Vidal, F.S. Pacheco, N.O. Barros, A. Assireu, J. Ometto, A.C.P. Cimbleris and J.J. Cole, 2010, Variability of carbon dioxide flux from tropical (Cerrado) hydroelectric reservoirs, Aquatic Sciences, Vol.72. No.3, Jun, pp. 283-293, 1015-1621.
Siyue Li. X.X. Lu, 2012, Uncertainties of carbon emission from hydroelectric Reservoirs, DOI 10.1007/s11069012-0127-3.

St Louis, V. L., C. A. Kelly, E. Duchemin, J.W.M. Rudd and D.M. Rosenberg, 2000, Reservoir surfaces as sources of greenhouse gases to the atmosphere: A global estimate, Bioscience 50, pp. 766-775.

Teodoru, C.R., Y.T. Prairie and P.A. Del Giorgio, 2010, Spatial Heterogeneity of Surface $\mathrm{CO}_{2}$ Fluxes in a Newly Created Eastmain-1 Reservoir in Northern Quebec, Canada, Ecosystems, Vol, 14. No.1, Jan, pp, 28-46, 1432-9840.

Tremblay, A., M. Lambert and L. Gagnon, 2004, Do hydroelectric reservoirs emit greenhouse gases? Environ. Manage, 33, S509-S517.

Tremblay, A., J. Bastien, M. Bonneville, P.D. Giorgio,M. Demarty, M. Garneau, L. Pelletier, Y. Prairie, N. Roulet, I. Strachan and C. Teodoru, 2010, Net Greenhouse Gas Emissions at Eastmain 1 Reservoir, Quebec, Canada, World Energy Congress, Montréal, http://www.eastmain1.org

\section{CALENDAR OF EVENTS - WATER RESOURCES}

26-30 August, 2012: 4th International Disaster and Risk Conference IDRC Davos 2012. Location: Davos, Switzerland. Contact Email: worldwaterweek@congrex.com. More info: http:// www.worldwaterweek.org/

28-30 August, 2012: International Conference on Scour and Erosion sponsored by Societe Hydrotechnique de France. Location: Paris, France. Contact Email: contact@shf-hydro.org. More info: www.shf-hydro.org

28-29 August, 2012: International Water Resource Economics Consortium. Location: Stockholm, Sweden. More info: www.worldwaterweek.org/ iwrec

9-12 September, 2012: Water Security and Emergency Preparedness Conference \& Exposition (WSEPC) 2012. Location: St. Louis, MO, USA. More info: www.awwa.org

12-14 September, 2012: SimHydro 2012: New Frontiers of Simulation, Modeling in Fluid Mechanics, Hydraulics and Hydrology sponsored by Societe Hydrotechnique de France. Location: Nice, France. Contact Email: contact@shf-hydro. org. More info: www.shf-hydro.org

12-15 September, 2012: British Dam Society Conference. Location: Leeds, UK. Contact Email: bds@ice.org.uk. More info: www.britishdams.org

14-16 September, 2012: Water Resources and Wetlands. Location: Tulcea, Romania. More info: http://www.limnology.ro/water2012/committees. html

16-21 September, 2012: Dam Safety 2012. Location: Denver, Canada. More info: www.awwa.org

22-26 September, 2012: Canadian Dam Association
Annual Conference. Location: Saskatoon, Saskatchewan, Canada. More info: www.cda. ca/2012conference

24-27 September, 2012: 3rd International Interdisciplinary conference on Predications for Hydrology, Water Resources and Changing Global Environment. Location: Vienna, Austria. More info: www.web.natur.cuni.cz/hydropredict2012/

8-11 October, 2012: 15th International River Symposium. Location: Melbourne, Australia. More info: http://www.riversymposium.com

8-11 October, 2012: 1st International Dam World Conference. Location: Maceio, Brazil. Contact Email: eliane@lnec.pt. More info: www. waterpowemagazine.com

21-23 October, 2012: Power of Water Canada Conference. Location: Ontario, Canada. More info: http://conference.owa.ca/

15-19 October, 2012: Storm Warning: Water, Energy and Climate Security in a Changing World. Location: Banff, Canada. More info: http://www. stormwarning2012.ca

5-9 November, 2012: 2nd International Conference of Water Resources. Location: Langkawi, Malaysia. More info: http://seminar.utmspace.utm.my/ icwr2012/

14-16 November, 2012: Main Sustainable Hydraulic Developments sponsored by Societe Hydrotechnique de France. Location: Paris, France. More info: www.shf-hydro.org

16-17 November, 2012: Water Crisis Management under Changing Climate Change. Location: Bhubaneswar, India. More info: http://www.gugly. org/National\%20Conference\%202012.htm 